\title{
EFEKTIVITAS DAYA HAMBAT CAMPURAN EKSTRAK RUMPUT LAUT (Gelidium latifolium) DAN EKSTRAK JERUK NIPIS (Citrus aurantifolia) TERHADAP Candida albicans SECARA IN VITRO
}

\author{
Duddy Satrianugraha ${ }^{1}$, Irwan Meidi Loebis ${ }^{1}$, Nur Fitriyani Amardina ${ }^{1}$ \\ ${ }^{1}$ Fakultas Kedokteran Universitas Swadaya Gunung Jati
}

Email: duddy.satrianugraha@gmail.com

\begin{abstract}
Candida albicans infection could maninfest as a superficial to systemic infection. Seaweed and essential oil of lemon extract were proven to inhibit Candida albicans. Limited studies on the seaweed and lemon mix extractas on antifungal sparked our interest to conduct research on this topic. To compare the effectiveness of inhibitory mixture of seaweed and lemon mix extract on Candida albicans in vitro. The research uses Posttest Only Control Group Design method. There were 7 groups, 2 control groups and 5 treatment groups given mixture of seaweed and lime mix extract in the ratio of $4: 0,3: 1,2: 2,1: 3$, and $0: 4$.Mean inhibitory disc lenght showed of seaweed and lime mix extract in the ratio of $4: 0,3: 1,2: 2,1: 3$, and $0: 4(3,62 \mathrm{~mm}, 25,5 \mathrm{~mm}, 31 \mathrm{~mm}, 42,5 \mathrm{~mm}$ and $42,5 \mathrm{~mm}$ with $\mathrm{P}<0,05)$. In multifariat test, the significance value was $\mathrm{P}<0.05$, there was at least a difference of mean between the two treatment groups. In post hoc test, the value was $\mathrm{P}<0,05$ in 9 pairs of treatments and the value was $\mathrm{P}>0,05$ in 9 pairs of treatments. The mixture of seaweed extract and lime extract in the ratio of $4: 0,3: 1,2: 2,1: 3$, and 0:4 proved to inhibit Candida albicans.
\end{abstract}

Keywords: Inhibitance, Candida albicans, mixture of seaweed extract and lime extract

\section{ABSTRAK}

Infeksi Candida albicans dapat berupa infeksi superfisial hingga sistemik. Ekstrak rumput laut dan minyak atsiri ekstrak jeruk nipis terbukti dapat menghambat pertumbuhan Candida albicans. Belum adanya penelitian mengenai penggunaan jeruk nipis dan rumput laut secara bersamaan sebagai anti jamur, menarik peneliti untuk meneliti masalah ini. Membandingkan efektivitas daya hambat campuran ekstrak rumput laut dan ekstrak jeruk nipis terhadap Candida albicans secara in vitro. Penelitian ini menggunakan rancangan penelitian Postest Only Control Group Design. Dibuat 7 perlakuan, 2 perlakuan kontrol dan 5 kelompok perlakuan yang diberi campuran ekstrak rumput laut dan ekstrak jeruk nipis dengan perbandingan 4:0, 3:1, 2:2, 1:3, dan 0:4. Hasil rerata daya hambat campuran ekstrak rumput laut dan ekstrak jeruk nipis dengan perbandingan 4:0, 3:1, 2:2, 1:3, dan 0:4 (3,62 mm, 25,5 mm, $31 \mathrm{~mm}, 42,5 \mathrm{~mm}$ dan 42,5 mm dengan $\mathrm{P}<0,05$ ). Hasil uji multifariat menunjukan nilai signifikansi $\mathrm{P}<0,05$, maka dapat dikatakan bahwa paling tidak terdapat perbedaan rerata antar dua kelompok perlakuan. Hasil uji post hoc menunjukan 9 pasang perlakuan memiliki nilai $\mathrm{P}<0,05$ dan 6 pasang perlakuan memiliki nilai $\mathrm{P}>0,05$. Campuran ekstrak rumput laut dan ekstrak jeruk nipis dengan perbandingan 4:0, 3:1, 2:2, 1:3, 0:4 memiliki daya hambat terhadap pertumbuhan Candida albicans.

Kata kunci: Daya hambat, Candida albicans, Campuran ekstrak rumput laut dan jeruk nipis.

\section{PENDAHULUAN}

Candida albicans merupakan spesies yang paling banyak ditemukan pada pasien dengan kandidiasis. Meskipun saat ini terjadi perubahan agen penyebab menjadi Candida non-albicans, akan tetapi Candida albicans masih tetap mendominasi. Di Amerika Serikat, kandidiasis akibat Candida albicans memiliki persentase sebesar $45 \%$ pada pasien dewasa, sedangkan kandidiasis akibat Candida glabrata pada dewasa sebesar 21\% dan Candida parapsilosis sebesar $12 \%$. Candida albicans 
memiliki tingkat mortalitas yang lebih tinggi dibandingkan spesies Candida lain, yaitu sebesar $47 \%{ }^{1}$.

Kandidiasis adalah penyakit akibat infeksi Candida sp. Pengobatan untuk penyakit kandidiasis salah satunya adalah nystatin. Nystatin yang tersedia di pasaran tersedia dalam dua bentuk yaitu obat oles dan obat cair. Namun, nystatin memiliki efek samping seperti kulit berwarna kemerahan dan iritasi, diare, mual muntah, serta iritasi pada mulut. Oleh karena itu perlu dikembangkan obat antijamur baru yang dapat digunakan untuk mengobati infeksi Candida albicans dengan efek samping yang minimal ${ }^{2}$.

Jeruk nipis (Citrus aurantifolia) merupakan salah satu tanaman toga yang banyak dibudidayakan oleh masyarakat. Selain harganya yang murah, jeruk nipis mudah didapatkan pada setiap musim. Masyarakat sering menggunakan jeruk nipis baik untuk bumbu masakan maupun untuk obat tradisional, karena jeruk nipis mengandung minyak atsiri yang berfungsi sebagai antijamur. Penelitian yang dilakukan oleh Jumar mengenai tumbuhan jeruk nipis menunjukkan bahwa ekstrak etanol buah jeruk nipis mampu menghambat pertumbuhan Candida albicans, dikarenakan jeruk nipis mengandung senyawa limonen $\gamma$ - terpinen, alkaloid, saponin, dan $\operatorname{tanin}{ }^{3,4,5}$.

Rumput laut (Gelidium latifolium.) merupakan tanaman yang banyak tumbuh di laut Indonesia, terutama di laut selatan. Di Indonesia, rumput laut dapat tumbuh liar maupun dibudidayakan oleh masyarakat. Selain rasanya yang enak, rumput laut sering dijadikan olahan minuman maupun makanan, karena rumput laut dapat diolah dalam bentuk kering maupun basah. Rumput laut juga digunakan sebagai obat trasisional oleh masyarakat. Penelitian oleh Lutfiyanti menunjukkan bahwa rumput laut jenis Gelidium latifolium mampu menghambat pertumbuhan Candida albicans, karena memiliki komponen senyawa bioaktif berupa alkaloid, triterpenoid, flavonoids dan steroid yang memiliki potensi sebagai antijamur alami ${ }^{6,7}$.

Berdasarkan penjelasan diatas, belum adanya penelitian mengenai penggunaan jeruk nipis dan rumput laut secara bersamaan sebagai antijamur, sehingga menarik peneliti untuk meneliti masalah ini. Berdasarkan perbedaan senyawa antijamur yang terkandung dalam jeruk nipis dan dan rumput laut, diharapkan dapat memberikan hasi yang maksimal dalam menghambat pertumbuhan Candida albicans.

Tujuan penelitian ini adalah Untuk mengetahui efektivitas daya hambat campuran ekstrak rumput laut (Gelidium latifolium) dan ekstrak jeruk nipis (Citrus aurantifolia) terhadap Candida albicans.

\section{METODE PENELITIAN}

Penelitian ini adalah penelitian eksperimental Laboratorium dengan rancangan penelitian Postest Only Control Group Design yang menggunakan jamur sebagai subjek penelitian. Rancangan yang digunakan adalah rancangan acak lengkap (RAL) yang terdiri dari 7 kelompok perlakuan. Kelompok perlakuan terdiri dari $\mathrm{P}(1), \mathrm{P}(2), \mathrm{P}(3), \mathrm{P}(4)$ dan $\mathrm{P}(5)$ yaitu pemberian campuran ekstrak rumput laut (Gelidium latifolium) dan ekstrak jeruk nipis (Citrus aurantifolia) dengan perbandingan 4:0, 3:1, 2:2, 1:3, dan 0:4. Kelompok kontrol yaitu $\mathrm{P}(-)$ dan $\mathrm{P}(+)$, kontrol negatif yaitu jamur yang tumbuh tanpa ada perlakuan, sedangkan kontrol positif yaitu jamur dengan pemberian obat nystatin. Pengukuran daya hambat campuran ekstrak jeruk nipis dan ekstrak rumput laut terhadap Candida albicans dilakukan dengan metode difusi agar menggunakan sumuran. Sumuran dibuat pada masing-masing cawan petri dengan diameter $\pm 1 \mathrm{~cm}$, masing-masing sumuran ditetesi larutan campuran ekstrak jeruk nipis dengan konsentrasi $100 \%$ dan ekstrak rumput laut yang telah diencerkan dengan etanol dengan konsentrasi $60 \mathrm{mg} / \mathrm{ml}$, dengan perbandingan masing-masing campuran ekstrak 
(Rumput laut : Jeruk nipis) 4:0, 3:1, 2:2, 1:3, dan 0:4. Untuk kontrol positif sumuran ditetesi larutan nystatin dengan konsentrasi $20 \%$, sedangkan kontol negatif tidak diberi perlakuan. Media diinkubasi pada suhu $37^{\circ} \mathrm{C}$ selama 4x24 jam, selanjutnya diamati diameter zona hambat yang terbentuk disekeliling sumuran dan dilakukan pengukuran dengan menggunakan penggaris dengan hasil pengukuran dinyatakan dalam milimeter $(\mathrm{mm})^{8}$.

\section{HASIL}

Berdasarkan hasil pengukuran didapatkan bahwa campuran ekstrak rumput laut dan ekstrak jeruk nipis dapat menghambat pertumbuhan jamur Candida albicans secara in vitro. Daya hambat pertumbuhan jamur oleh ekstrak dapat dilihat dari diameter zona hambatnya. Apabila diameter zona hambat $\leq 10 \mathrm{~mm}$ maka dikatakan tidak ada respons hambat, diameter zona hambat 11-15 mm dikatakan lemah, diameter zona hambat 16-20 mm dikatakan sedang, dan diameter zona hambat $>20 \mathrm{~mm}$ dikatakan kuat ${ }^{9}$. Dari klasifikasi tersebut maka dapat digolongkan bahwa daya hambat campuran ekstrak rumput laut (Gelidium latifolium) dan ekstrak jeruk nipis (Citrus aurantifolia) dengan perbandingan 4:0 tidak memiliki respons daya hambat, dengan rata-rata diameter zona hambat sebesar 3,62 $\mathrm{mm}$. Daya hambat campuran ekstrak rumput laut dan ekstrak jeruk nipis dengan perbandingan 3:1, 2:2, 1:3, dan 0:4 memiliki daya hambat yang kuat dengan ratarata diameter zona hambat sebesar $25,5 \mathrm{~mm}, 31 \mathrm{~mm}$, 42,5 mm, dan 42,5 mm. Berdasarkan data tersebut didapatkan campuran ekstrak rumput laut dan ekstrak jeruk nipis dengan perbandingan $3: 1,2: 2,1: 3$, dan $0: 4$ lebih baik dari campuran ekstrak rumput laut dan ekstrak jeruk nipis dengan perbandingan 4:0, hal tersebut dikarenakan daya hambat yang dihasilkan campuran ekstrak rumput laut dan ekstrak jeruk nipis dengan perbandingan $3: 1,2: 2,1: 3$, dan $0: 4$ lebih kuat dibandingkan perbandingan 4:0.

\section{PEMBAHASAN}

Berdasarkan hasil penelitian dapat terlihat bahwa daya hambat terjadi lebih baik pada campran ekstrak dengan jeruk nipis. ekstrak jeruk nipis (Citrus aurantifolia) mengandung senyawa limonen $\gamma$-terpinen, alkaloid, saponin, dan tanin ${ }^{5}$. Limonen merupakan senyawa hidrokarbon yang mempunyai kemampuan antimikroba dengan bekerja menghancurkan membran sel mikroba. Mekanismenya diduga dengan merusak integritas membran ${ }^{10}$. Saponin dapat merusak membran sel pada jamur, sehingga menyebabkan kebocoran sel yang akhirnya memacu terjadinya kematian sel. Tanin dapat menghambat pertumbuhan jamur dengan mengganggu struktur membran sel dan menghambat pembentukan dinding sel pada jamur ${ }^{12}$.

Ekstrak rumput laut (Gelidium latifolium) sendiri mengandung senyawa alkaloid, triterpenoid, flavonoids dan steroid. Terpenoid, termasuk triterpenoid dan steroid merupakan senyawa bioaktif yang memiliki fungsi sebagai antijamur. Triterpenoid berperan dalam menghasilkan zona hambat karena sifat toksiknya, sehingga ketika senyawa aktif terserap oleh jamur patogen dapat menimbulkan kerusakan pada organelorganel sel, menghambat kerja enzim di dalam sel, dan pada akhirnya akan terjadi penghambatan pertumbuhan jamur patogen ${ }^{12}$. Senyawa flavonoid quercetin dapat menghambat jamur dengan cara merusak DNA, serta sophoraflavone G dan (-)-epigallocatechin gallate menghambat jamur dibagian membran sitoplasma, dan licochalconesA dan $\mathrm{C}$ menghambat metabolisme energi pada jamur ${ }^{13}$. Steroid dapat berfungsi sebagai antijamur karena sifat lipofilik yang dimiliki oleh steroid dapat menghambat perkecambahan spora dan perbanyakan miselium pada jamur.(32) Alkaloid dapat berfungsi sebagai antijamur dengan cara menghambat esterase, DNA serta RNA polymerase dan dapat menghambat respirasi sel dan berperan dalam interaksi DNA. 
Dari hasil dan Pembahasan didapatka kesimpulan :

1. Ekstrak rumput laut memiliki daya hambat yang lemah terhadap pertumbuhan Candida albicans.

2. Ekstrak jeruk nipis memiliki daya hambat yang kuat terhadap pertumbuhan Candida albicans.

3. Campuran ekstrak rumput laut dan ekstrak jeruk nipis dengan perbandingan 3:1, 2:2, 1:3 memiliki daya hambat yang kuat terhadap pertumbuhan Candida albicans.

4. Campuran ekstrak rumput laut dan ekstrak jeruk nipis dengan perbandingan 1:3 dan 0:4 sama efektifnya dalam menghambat pertumbuhan Candida albicans.

\section{Daftar pustaka}

1. Pappas PG. A prospective observational study of candidemia : epidemiology, therapy, and influences on mortality in hospitalized adult and pediatric patients. CID. 2003;vol 37.

2. Bertram G katzung, Susan B Masters AJT. Farmakologi Dasar dan Klinik. ed 12. Jakarta: EGC; 2014.

3. Nwauzoma, Akagbuo B. Biological Activity of Crude Extracts of Citrus species from Nigeria [Internet]. 2013. Available from: http://www.sciencepub.net/nature

4. Effendi, Widjanarko. Distilasi dan Karakterisasi Minyak Atsiri Rimpang Jeringau (Acorus calamus) dengan Kajian Lama Waktu Distilasi dan Rasio Bahan : Pelarut. Journal dan Agroindustri. 2008;vol 2:1-8.

5. Jumar M. Uji Efektifitas Ekstrak Etanol Buah Jeruk Nipis (Citrus aurantifolia) dalam Menghambat Pertumbuhan Jamur Candida Albicans. Banda Aceh: Fakultas Kedokteran Unsyiah; 2013; 22-24

6. Elsie BH, MS Dhanarajan. Evaluation of Antimicrobial Activity and Phytochemical Screening of Gelidium acerosa. Bharathiar University, india; 2010.

7. Lutfiyanti R, Ma'ruf WF, Dewi EN. Aktivitas Antijamur Senyawa Bioaktif Ekstrak Gelidium latifolium Terhadap Candida albicans. J Pengolah dan Bioteknol Has Perikan [Internet]. 2012;1(1):26-33. Available from: http://ejournal-s1.undip.ac.id/index. php/jpbhp/article/view/655
8. J Vandepitte. Prosedur Laboratorium Dasar untuk Bakteriologi Klinis. Jakarta: EGC; 2010. 134-137 p.

9. Greenwood D. Antibiotics, Susceptibility (sensitivity) Test Antimicrobial and Chemoterapy. USA: Mc Graw Hill Company; 1995. $47 \mathrm{p}$

10. Aliyu AB, Musa AM, Abdullah MA, Ibrahim MB TM. Activity of Saponin Fraction of Anisopus manii against some pathogenic microorganisms. J Med plants Res. 2011;vol 5:6709-13

11. Hong LS, Ibrahim D, Kassim J. Gallic acid: an anticandidal compund in hidrolysable tannin extracted from the barks of Rhizophora apiculate Blume. Journal of Applied Pharmaceutical Science; 2011. 75-79 p

12. Ismaini, L. Aktivitas Antifungi Ekstrak (Centella asiatica (L.) Urban terhadap Fungi Patogen pada Daun Anggrek (Bulbophyllum flavidiflorum Carr). Jurnal Penelitian Sains; 2011. Vol 14 No 1.

13. Cushnie T, Lamb A. Antimicrobal activity of flavonoids. Pubmed; 2006. Vol 2. $181 \mathrm{p}$

14. Subhisha, S. Dan A. Subramoniam. Antifungal Activities of a Steroid From Pallavicinia lyellii, a Liverwort. India: Tropical Botanic Garden and Research Institute; 2005. 